\title{
Old magma and a new, intrusive trigger: using diffusion chronometry to understand the rapid-onset Calbuco eruption, April 2015 (Southern Chile)
}

\author{
Eduardo Morgado ${ }^{1,2}$ (D) Daniel J. Morgan ${ }^{1} \cdot$ Angelo Castruccio $^{2,3} \cdot$ Susanna K. Ebmeier ${ }^{1} \cdot$ Miguel-Ángel Parada $^{2,3}$. \\ Raimundo Brahm ${ }^{4}$. Jason Harvey ${ }^{1} \cdot$ Francisco Gutiérrez $^{5} \cdot$ Richard Walshaw $^{1}$
}

Received: 19 February 2019 / Accepted: 10 June 2019 / Published online: 25 June 2019

(c) The Author(s) 2019

\begin{abstract}
In April 2015, an unpredicted rapid-onset eruption occurred at Calbuco Volcano, Southern Andes of Chile. This event consisted of two, sub-Plinian eruptions separated by a few hours. By analysis of Fe-Ti exchange between ilmenite and titanomagnetite crystals in samples of erupted material, we determine timescales of pre-eruptive heating experienced at the partially solidified chamber base and constrain the magma residence time for the bulk of the carrier magma. Analysis of the $\mathrm{Fe}-\mathrm{Ti}$ oxide pairs from a sample retrieved from a pyroclastic density current deposit (Cal-160) shows that it was affected by a significant heating event (recording $70-220^{\circ} \mathrm{C}$ of heating), while other collected samples did not record this late heating. This sample is interpreted to represent a piece of crystal mush located at the bottom of a prolate, ellipsoidal mush reservoir, mobilised $<4$ days before the eruption by a triggering pulse of mafic magma considerably hotter than the typical magmatic temperature of the reservoir. Another two fall deposit samples (lapillus, Cal-149Tb and Cal-155) of the eruption are interpreted to represent resident, eruptible magmas that did not interact with any magma recharge immediately prior to or during the eruption. We infer that these magmas had been at eruption temperature for some years based on their extensively equilibrated Fe-Ti oxides.
\end{abstract}

Keywords Calbuco volcano $\cdot$ Diffusion chronometry $\cdot$ Fe-Ti oxides $\cdot$ Magmatic timescales $\cdot$ Rapid-onset eruption

Communicated by Mark S Ghiorso.

Electronic supplementary material The online version of this article (https://doi.org/10.1007/s00410-019-1596-0) contains supplementary material, which is available to authorized users.

Eduardo Morgado

eeeem@leeds.ac.uk

1 Institute of Geophysics and Tectonics, School of Earth and Environment, University of Leeds, Leeds LS2 9JT, UK

2 Centro de Excelencia en Geotermia de los Andes (CEGA-FONDAP 15090013), Santiago, Chile

3 Departamento de Geología, Facultad de Ciencias Físicas y Matemáticas, Universidad de Chile, Santiago, Chile

4 Volcanic Risk Solutions, IAE, Massey University, Palmerston North 4442, New Zealand

5 GeoExpedition, Las Barrancas 25, Pirque, 9480000 Santiago, Chile

\section{Introduction}

Forecasting eruptions and tracking the evolution of magmatic systems are fundamental goals for volcanology. Before many eruptions, geochemical and geophysical time-series data are consistent with changes in magmatic conditions over months to years (e.g., Carapezza and Federico 2000; Brenguier et al. 2008; Madonia et al. 2013; Delgado et al. 2014; Einarsson 2018; Ebmeier et al. 2018). Some explosive eruptions, however, are preceded by unrest of only hours to days (e.g., El Reventador volcano in 2002, VEI 4, Hall et al. 2004; Rabaul volcano in 1994, VEI 4, Roggensack et al. 1996; Chaitén volcano in 2008 (VEI 5), Castro and Dingwell 2009), although the certainty with which we can identify such events is limited by the availability and temporal resolution of monitoring data.

During April 2015, two sub-Plinian eruptive events (VEI 4, Romero et al. 2016; Van Eaton et al. 2016) occurred at Calbuco Volcano, Southern Chile, after $\sim 54$ years of quiescence (since the last major eruption, in 1961). Calbuco is a 
Late Pleistocene-Holocene composite stratovolcano (LópezEscobar et al. 1992; Sellés and Moreno 2011) located in the Central Southern Volcanic Zone of the Chilean Andes and is currently rated the third most hazardous of Chile's 90 active volcanoes (SERNAGEOMIN 2016, 2017). The 2015 Calbuco eruption was notable for being preceded only by seismic unrest of a very short duration. A 2-h long swarm of $\sim 140$ volcano-tectonic (VT) earthquakes began about $3 \mathrm{~h}$ before the first eruptive event, while the first long-period (LP) seismicity began just $1.5 \mathrm{~h}$ prior to the beginning of the first eruptive event (SERNAGEOMIN 2015a, b). Interferometric synthetic aperture radar (InSAR) measurements demonstrate that no significant deformation occurred in the months leading up to eruption at least up until $36 \mathrm{~h}$ before the eruption when the last pre-eruptive InSAR image was acquired (Delgado et al. 2017). Both subsequent satellite radar (Delgado et al. 2017; Nikkhoo et al. 2016) and tiltmeter measurements (Valderrama et al. 2015) captured co-eruptive subsidence during the first eruption consistent with a contracting source at depths of $8-11 \mathrm{~km}$ below the summit. Seven hours after the beginning of the first eruptive event (1.5 h duration), a second eruptive event started, following further LP and hybrid seismicity (Valderrama et al. 2015). The eruption produced pyroclastic density current (PDC) and fall deposits with bulk compositions of basaltic andesites (54-56 wt $\% \mathrm{SiO}_{2}$ ) with scarce andesites ( $\sim 58 \mathrm{wt} \% \mathrm{SiO}_{2}$; Castruccio et al. 2016). The mineral phases present are: plagioclase (two groups: $\mathrm{An}_{46-79}$ and $\mathrm{An}_{80-92}$ ), clinopyroxene $\left(\mathrm{En}_{43-47} \mathrm{Fs}_{9-15} \mathrm{Wo}_{40-45}\right)$, orthopyroxene $\left(\mathrm{En}_{67-71} \mathrm{Fs}_{26-31} \mathrm{Wo}_{2-3}\right)$, amphibole (edenite and pargasite), titanomagnetite (two groups: Xusp $\mathrm{Xu10-0.17}_{0 .} ; \mathrm{Xusp}_{0.42-0.46}$ ), and ilmenite $\left(\mathrm{Xilm}_{0.77-0.85}\right)$ (Castruccio et al. 2016; Morgado et al. 2019). A recent study (Morgado et al. 2019) identified a heating event that affected a mush reservoir as a potential trigger of this rapid-onset eruption, based upon temperatures of up to $1070{ }^{\circ} \mathrm{C}$ recorded in the rims of Fe-Ti oxide (ilmenite-titanomagnetite) crystal pairs $\left(\sim 120^{\circ} \mathrm{C}\right.$ above the ambient magma) using the thermoxybarometer of Ghiorso and Evans (2008).

We collected nine samples from fall and PDC deposits, three of which contain scarce $(<0.1 \mathrm{vol} \%)$ titanomagnetite and ilmenite grains in contact with each other (Cal-149Tb, Cal-155, and Cal-160). Significant compositional zoning and exchange are only recorded at the interface of $\mathrm{Fe}-\mathrm{Ti}$ oxide pairs in the highly crystalline sample Cal-160 ( 60\% crystallinity, obtained via image processing of pseudo coloured images through the freeware Jmicrovision), erupted during the second eruptive stage (Fig. 1). This sample has been associated in earlier work with the base of the prolate spheroid shape (Delgado et al. 2017) of the magma reservoir based on considerations of differences in whole-rock chemistry, crystallinity, and recorded heating (Morgado et al. 2019). In the rest of the samples ( $40 \%$ crystallinity, obtained via the same method as Cal-160), erupted during the first and second eruptive pulses, $\mathrm{Fe}-\mathrm{Ti}$ oxide pairs exhibit relatively homogeneous compositional profiles and, therefore, do not record the same late-stage heating (Morgado et al. 2019). These samples were associated with middle levels of the mentioned reservoir, and represent a mobilised, eruptible magma. In this work, we investigate the detailed timescales of heating in Cal-160 just before the eruption using $\mathrm{Fe}-\mathrm{Ti}$ interdiffusion chronometry in ilmenite-titanomagnetite phenocryst pairs. In addition, we calculate minimum timescales of re-equilibration in ilmenite-titanomagnetite phenocryst pairs from samples Cal-149Tb and Cal-155, to better constrain the history of the erupted magma.

Diffusion chronometry has often been used to calculate magmatic timescales associated with mush reservoir processes (e.g., Nakamura 1995; Martin et al. 2008; Hartley et al. 2016). The rapid interdiffusivity of $\mathrm{Fe}-\mathrm{Ti}$ in ilmenite and titanomagnetite, in comparison to ionic diffusion in silicate mineral phases (Freer and Hauptman 1978; Rutherford et al. 1993; Van Orman and Crispin 2010) at the same intensive magmatic conditions ( $\mathrm{P}, \mathrm{T}$, and $f \mathrm{O}_{2}$ ), allows us to use $\mathrm{Fe}-\mathrm{Ti}$ oxides to understand processes occurring shortly before eruption (Nakamura 1995; Coombs et al. 2000; Devine et al. 2003; Chertkoff and Gardner 2004; Tomiya et al. 2013).

\section{Thermometry and oxygen barometry}

Ilmenite solid solution (hematite and ilmenite end members, $\mathrm{Fe}_{2} \mathrm{O}_{3}$ and $\mathrm{FeTiO}_{3}$, respectively) and titanomagnetite solid solution (magnetite and ulvöspinel end members, $\mathrm{Fe}_{3} \mathrm{O}_{4}$ and $\mathrm{Fe}_{2} \mathrm{TiO}_{4}$, respectively) are suitable for Fe-Ti thermometry and oxygen barometry when grains are in contact with each other. The thermometry models are based on the temperaturedependent exchange $\mathrm{Fe}^{2+}+\mathrm{Ti}^{4+} \leftrightarrow 2 \mathrm{Fe}^{3+}$ (e.g., Ghiorso and Sack 1991; Ghiorso and Evans 2008; Sauerzapf et al. 2008) according to the equation

$\mathrm{Fe}_{2} \mathrm{O}_{3}$ (hematite) $+\mathrm{Fe}_{2} \mathrm{TiO}_{4}$ (ulvöspinel)
$\quad \leftrightarrow \mathrm{Fe}_{3} \mathrm{O}_{4}$ (magnetite) $+\mathrm{Fe}_{3} \mathrm{TiO}_{3}$ (ilmenite)

The oxygen barometer reported by Ghiorso and Evans (2008) is based on the redox equilibrium of hematite-magnetite with ulvöspinel buffer according to the equation:

$6 \mathrm{Fe}_{2} \mathrm{O}_{3}$ (hematite) $\leftrightarrow 4 \mathrm{Fe}_{3} \mathrm{O}_{4}$ (magnetite) $+\mathrm{O}_{2}$ (gas)

and the oxygen barometer reported by Sauerzapf et al. (2008) is based on the redox equilibrium of hematite-magnetite buffer according to the equation:

$6 \mathrm{FeTiO}_{3}$ (ilmenite) $+2 \mathrm{Fe}_{3} \mathrm{O}_{4}$ (magnetite)

$\leftrightarrow 6 \mathrm{Fe}_{2} \mathrm{TiO}_{4}$ (ulvöspinel) $+\mathrm{O}_{2}$ (gas)

All the methods used here to calculate intensive variables are based on the measured compositions of 

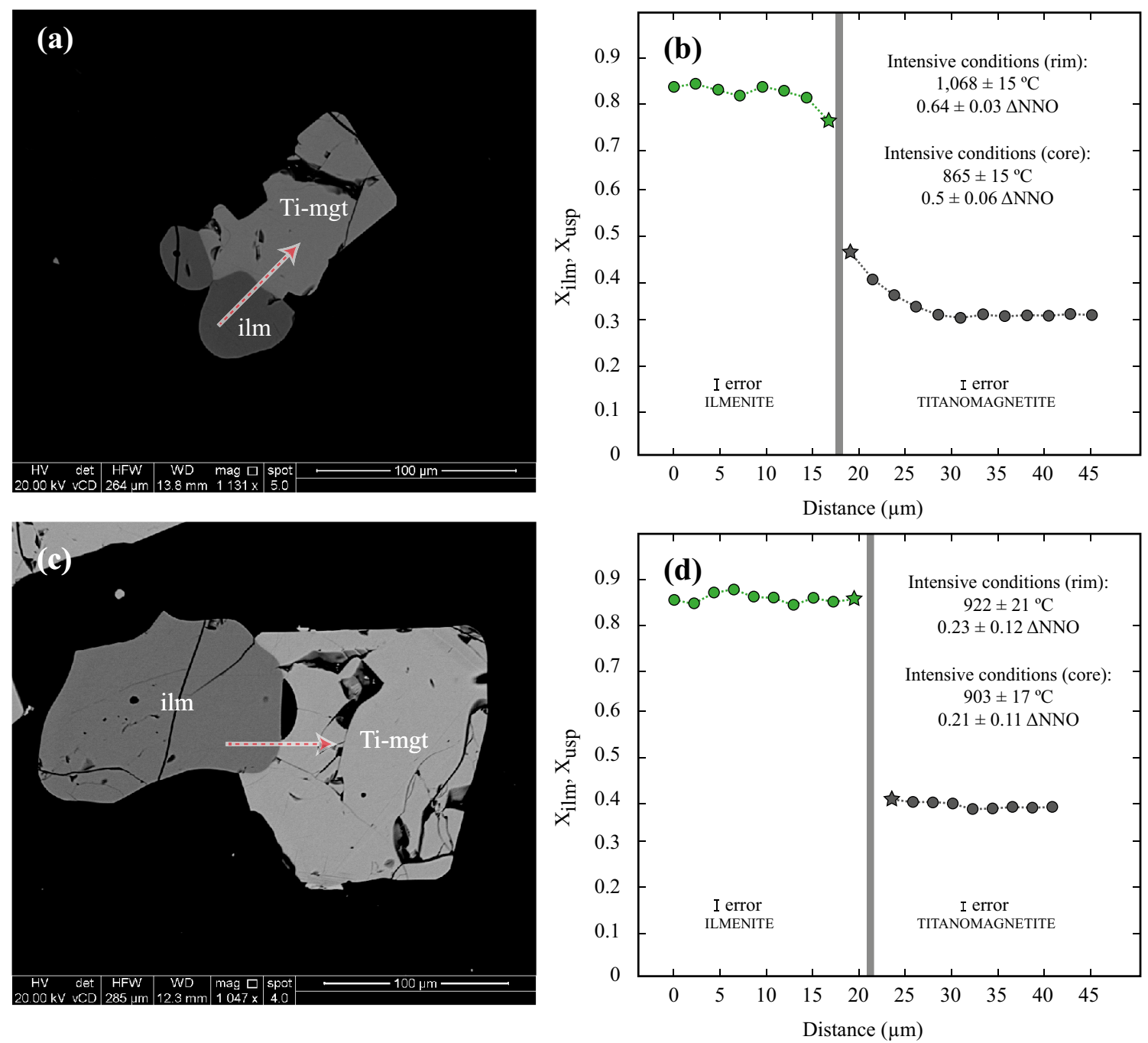

Fig. 1 Backscatter images of in-contact ilmenite-titanomagnetite pair from the sample Cal-160 (a) and from the sample Cal-155 (c), the arrows represent the direction of the profiles measured by electron probe micro-analysis (EPMA); EPMA profile across in-contact

ilmenite-titanomagnetite pairs from a (b) and from $\mathbf{c}(\mathbf{d})$. Core and rim (represented by the star) temperature and oxygen fugacity conditions were reported by Morgado et al. (2019), the associated errors come from measurement uncertainties

ilmenite-titanomagnetite grains that are in contact with each other. Equilibration is mediated via the kinetic process of diffusion, meaning that compositional changes occur at the boundary between the two oxide grains as a response to changes in both temperature and oxygen fugacity $\left(f \mathrm{O}_{2}\right)$, which must then propagate by diffusing gradually into crystal interiors (see details in Lasaga 1983). Whilst compositional re-equilibration between minerals upon heating is rapid at the interface, and represents the intensive conditions immediately before the eruption, it can be possible to ascertain from the crystal cores the intensive conditions present before any re-equilibration process took place (pre-heating conditions, see details in Lasaga and Jiang 1995) (Fig. 1).

In Cal-160, temperatures and oxygen fugacity conditions prior to heating were calculated using ilmenite and

titanomagnetite core compositions and correspond to an average temperature of $870{ }^{\circ} \mathrm{C}\left(\sigma=18{ }^{\circ} \mathrm{C}\right)$; and an average oxygen fugacity of $+0.6 \Delta \mathrm{NNO}(\sigma=0.18 \Delta \mathrm{NNO}$; Morgado et al. 2019). The compositions of ilmenite-titanomagnetite pairs close to the interface record the late-stage equilibrium in terms of the temperature and oxygen fugacity conditions experienced during the heating of the system just prior to eruption (average temperature: $1018^{\circ} \mathrm{C}, \sigma=45^{\circ} \mathrm{C}$; average oxygen fugacity: $+0.48 \Delta \mathrm{NNO}, \sigma=0.16 \Delta \mathrm{NNO}$; Morgado et al. 2019). The composition of the traverses measured from ilmenite to titanomagnetite represents only diffusion and are not significantly affected by measurement convolution effects or secondary fluorescence (details in next section).

In Cal-149Tb and Cal-155, the temperature and oxygen fugacity conditions were calculated using ilmenite and 
titanomagnetite core compositions and correspond to an average temperature of $933^{\circ} \mathrm{C}\left(\sigma=35^{\circ} \mathrm{C}\right)$; and an average oxygen fugacity of $0.3 \Delta \mathrm{NNO}(\sigma=0.14 \Delta \mathrm{NNO})$ (Morgado et al. 2019). The compositions of ilmenite-titanomagnetite pairs close to the interface yielded no significantly different magmatic intensive conditions.

The core compositions of ilmenite-titanomagnetite pairs show fairly constant compositional profiles, the crystal pairs passed the $\mathrm{Mg}-\mathrm{Mn}$ equilibrium chemical test (Fig. 2; Bacon and Hirschmann 1988), and there are no resorption textures. These features suggest that all the Fe-Ti oxides in contact were in equilibrium before heating. For this study, we use all the in contact ilmenite-titanomagnetite grains within the compositional and temperature range in which the thermoxybarometers were calibrated (Ghiorso and Evans 2008; Sauerzapf et al. 2008).

\section{Diffusion modelling: a tool to obtain magmatic timescales}

\section{Modelling approach}

The profile shapes observed in Fig. 1 of ilmenite-titanomagnetites from the sample Cal-160, suggest that the minerals are responding to the heating event, governed by Eqs. 1, 2, and 3. In practice, this leads to Ti enrichment in the titanomagnetite bordering ilmenite (Loomis 1983). Fe-Ti interdiffusion within titanomagnetite can be described and modelled using Fick's second law and the composition-dependent form of the diffusion equation:

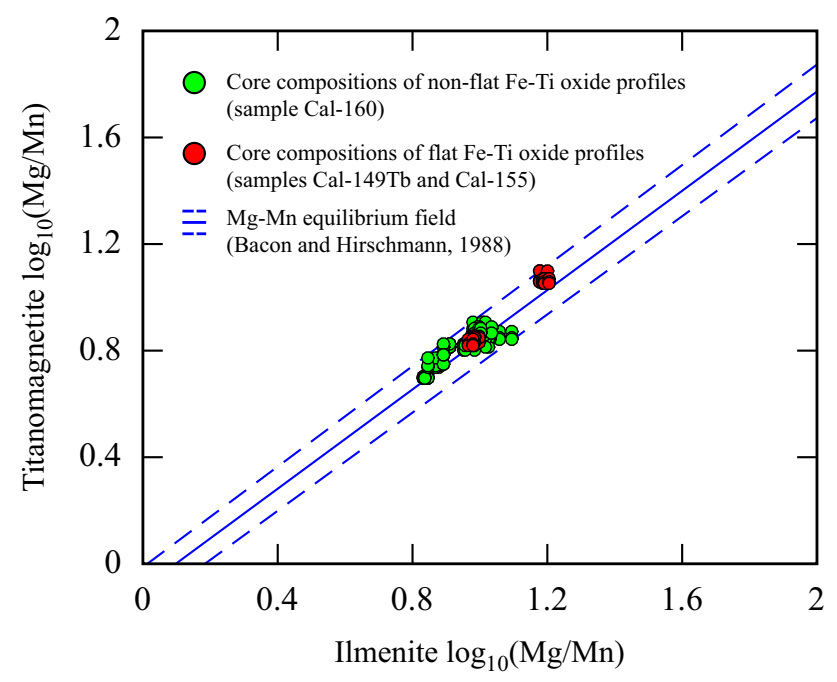

Fig. 2 Ilmenite-titanomagnetite $\mathrm{Mg}-\mathrm{Mn}$ chemical equilibrium test (Bacon and Hirschmann 1988) of the cores of the studied Fe-Ti oxide pairs. Red circles correspond to pairs from samples Cal-149Tb and Cal-155, while green circles correspond to pairs from sample Cal-160 (details in Supplementary Material 1) $\frac{\partial C(x, t)}{\partial t}=\frac{\partial}{\partial x}\left(D_{\mathrm{Ti}}^{*} \frac{\partial C(x, t)}{\partial x}\right)$,

where $C$ is composition, $t$ is time, $x$ is distance, and $D_{\mathrm{Ti}}^{*}$ is the diffusivity $\left(\mathrm{m}^{2} \mathrm{~s}^{-1}\right)$. This diffusivity (or Fe-Ti interdiffusivity) is calculated via Eq. 5 (Aragon et al. 1984):

$$
\begin{aligned}
D_{\mathrm{Ti}}^{*}= & D_{0}^{0} \exp \left(-\frac{E_{0}}{R T}\right)+(1-X) \\
& \times\left(D_{\mathrm{V}}^{0} \exp \left(-\frac{E_{\mathrm{V}}}{R T}\right)\left[\frac{1+X}{1-X}\right]^{8 / 3} f \mathrm{O}_{2}^{2 / 3}\right. \\
& \left.-D_{\mathrm{I}}^{0} \exp \left(-\frac{E_{\mathrm{I}}}{R T}\right)\left[\frac{1-X}{1+X}\right]^{8 / 3} f \mathrm{O}_{2}^{-2 / 3}\right),
\end{aligned}
$$

where $D_{0}^{0}, D_{\mathrm{V}}^{0}$, and $D_{\mathrm{I}}^{0}$ are internal diffusion coefficients (details in Supplementary Material 2); $E_{0}, E_{\mathrm{V}}$, and $E_{\mathrm{I}}$ are internal activation energies (cal mol ${ }^{-1}$; details in Supplementary Material 2); $T$ is temperature $(\mathrm{K}) ; R$ is the universal gas constant (cal mol $\left.{ }^{-1} \mathrm{~K}^{-1}\right), f \mathrm{O}_{2}$ is oxygen fugacity (atm), $X$ is the factor (from 0 to 1 ) representing the composition of the titanomagnetite solid solution $\left(\left(\mathrm{Fe}_{3} \mathrm{O}_{4}\right)_{1-X}\left(\mathrm{Fe}_{2} \mathrm{TiO}_{4}\right)_{X}\right)$. An example of diffusion modelling in ilmenite-titanomagnetite pairs from the sample Cal-160 is shown in Fig. 3a.

The ilmenite-titanomagnetite pairs in samples Cal$149 \mathrm{~Tb}$ and Cal-155 display compositional profiles with only weak zonation, and they are considered as largely equilibrated pairs that retain only weak disequilibrium. Although paired cores do consistently return temperatures lower than paired rims, the values are well within the uncertainty of the thermometry technique (see Supplementary Material 1). If we consider that previous heating has occurred, and that these crystals have been largely reequilibrated, then minimum timescales of re-equilibration can be estimated in equilibrated pairs. Equally, the lack of any significant deviations between interface and cores can be taken to signify that conditions have been stable for a considerable length of time. We can use Fe-Ti interdiffusion chronometry to constrain re-equilibration timescales in titanomagnetite grains following Eqs. 4 and 5. In performing these calculations the initial core composition has to be assumed, as no part of the profile has escaped modification. Using a low value of $X_{\mathrm{Ti}}$, comparable to the lowest value found in the system would in theory yield the longest answer; using the highest value of $X_{\mathrm{Ti}}$ for the core would theoretically yield the shortest answer as it would require less modification. We have used the latter parameter, based upon the value $X_{\mathrm{Ti}}=0.14$, from the Cal-160 crystals, to place a minimal constraint for the long re-equilibration time of crystals in Cal-155 and Cal-149Tb. We would note that the curvature of the profile is such that it is actually relatively insensitive to the choice of initial condition. 


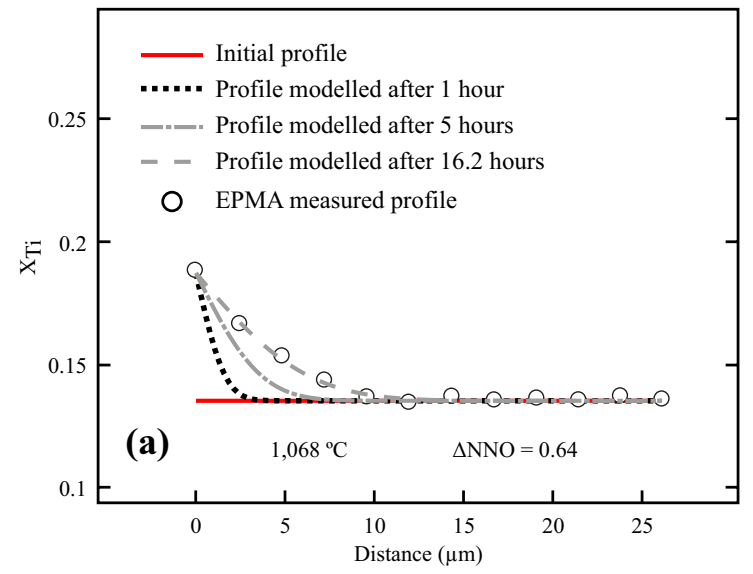

Fig. 3 Examples of Fe-Ti interdiffusion, showing the evolution of molar composition $\left(X_{\mathrm{Ti}}=\mathrm{Ti} /\left(\mathrm{Ti}+\mathrm{Fe}_{\mathrm{tot}}\right)\right)$ : a profile of titanomagnetite over time from the sample Cal-160, representing the bottom of the magma reservoir (Table 1 and Supplementary Material 1) and $\mathbf{b}$ re-

Table 1 Time necessary to reach equilibrium conditions in crystal boundaries of sample Cal-160

\begin{tabular}{lll}
\hline Pair name & Boundary eq. time $(\mathrm{s})$ & Resolution $(\mu \mathrm{m})$ \\
\hline f1_p1 & 0.3 & 0.01 \\
f1_p2 & 0.2 & 0.01 \\
f1_p3 & 0.5 & 0.01 \\
f13_p2 & 0.2 & 0.01 \\
f17_p1 & 0.1 & 0.01 \\
f17_p2 & 0.1 & 0.01 \\
f17_p4 & 0.4 & 0.01 \\
fb_p1 & 0.5 & 0.01 \\
fe_p1 & 0.3 & 0.01 \\
ff_p1 & 0.3 & 0.01 \\
ff_p2 & 0.6 & 0.01 \\
fh_p1 & 0.1 & 0.01 \\
\hline
\end{tabular}

\section{Compositional equilibrium in grain boundaries}

The propagation of a re-equilibrating boundary composition during ionic exchange between ilmenite and titanomagnetite can be considered as similar to the Arrhenius kinetic formula for thermally activated processes (cf. Lasaga 1979; Loomis 1983). Thus, we use Fick's second law for non-steady state diffusion (Eq. 4) and diffusivity following Aragon et al.'s (1984) equation (Eq. 5) to determine the timescale in which the composition in equilibrium with the new intensive physical condition is

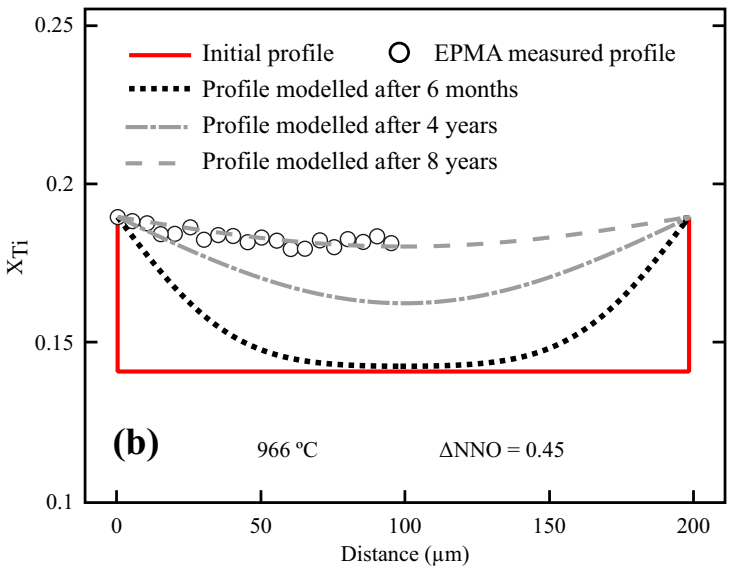

equilibration profile of titanomagnetite over time from the sample Cal-149Tb, representing the middle of the magma reservoir (Table 2 and Supplementary Material 1)

reached in the grain interface. Even ignoring the significant diffusion enhancement in the grain interface inferred by Hammond and Taylor (1982), we can calculate that compositions within $10 \mathrm{~nm}$ of the interface will attain a new equilibrium in less than $1 \mathrm{~s}$ for all the ilmenite-titanomagnetite pairs. The results are shown in Table 1 and form a basis for assuming instantaneous compositional equilibrium on the interface in subsequent modelling. Such models, where equilibrium is reached instantaneously at the boundary have been used successfully in previous studies (cf. Lasaga 1979; Venezky and Rutherford 1999). In addition, the asymmetric shape of the composition profiles suggests that ionic exchange at the crystal boundary is the dominant process. We, therefore, interpret that a buffered exchange between the two minerals dominates the profile shapes, rather than infiltration of a third component (e.g., melt) along the grain boundary. Videos representing the evolution of compositional re-equilibration in grain boundaries are available in Supplementary Material 4.

\section{Uncertainties}

We obtain the uncertainties of diffusivity from the error propagation of temperature $(T)$, oxygen fugacity $\left(f \mathrm{O}_{2}\right)$, and composition of titanomagnetite $(X)$ following Eq. 6 (details are available as Supplementary Material 1). Finally, we consider the intrinsic experimental uncertainty in the calculation of $D_{\mathrm{Ti}}^{*}(0.1 \log$ units, reported by Aragon et al. 1984).

$\varepsilon\left(f\left(T, f \mathrm{O}_{2}, X\right)\right) \approx \sqrt{\left(\frac{\partial f}{\partial T} \varepsilon(T)\right)^{2}+\left(\frac{\partial f}{\partial f O_{2}} \varepsilon\left(f \mathrm{O}_{2}\right)\right)^{2}+2\left(\frac{\partial f}{\partial T}\right) \cdot\left(\frac{\partial f}{\partial f \mathrm{O}_{2}}\right) \cdot \operatorname{cov}\left(\varepsilon\left(T, f \mathrm{O}_{2}\right)\right)+\left(\frac{\partial f}{\partial X} \varepsilon(X)\right)^{2}}$. 
We use the sum of the squares of the differences (SSD) to assess the best-fitting curve. We consider the uncertainty of the curve fitting on the diffusive length scale (cf. Gualda et al. 2012) as negligible, because the measured profiles show high precision and low noise (details in Supplementary Material 5).

\section{Do the measured profiles represent diffusion?}

We can be confident that the profiles measured from ilmenite to titanomagnetite from the sample Cal-160 represent only diffusion and are not significantly affected by measurement convolution effect for the following reasons:

1. Modelling of electron-sample interactions with the software CASINO (Hovington et al. 1997; Drouin et al. 2007) suggests that, at the analytical conditions of $15 \mathrm{keV}$ accelerating potential and a $30 \mathrm{nA}$ focused beam, the interaction volume in the samples is of $\sim 2 \mu \mathrm{m}$ width, which we use as the analytical point spacing. In addition, the vertical interaction is $<1.5 \mu \mathrm{m}$ length (details in Supplementary Material 6).

2. We can rule out secondary fluorescence effects from analysis of ilmenite-titanomagnetite pairs from the sample Cal-160, because in Cal-149Tb and Cal-155, where equilibrium appears to be reached, compositional profiles do not show the characteristic enrichment/depletion effects that we see close to the interfaces of those compositional profiles from Cal-160, which suggests that these data represent true disequilibrium profiles.

\section{Timescales from heating to eruption}

The calculated timescales obtained from the sample Cal160 are associated with the recording of a heating event up to 4 days before the eruption (Table 2; Fig. 4). On the other hand, the results of minimum re-equilibration diffusion modelling in the crystal pairs from the samples Cal-149Tb and Cal-155 yield timescales of the order of years. All the timescales are consistent with those calculated using Aggarwal and Dieckmann's (2002a, b) equations for Fe-Ti (inter)diffusivity in titanomagnetite.

\section{Cal-160}

Our modelled timescales between the heating event and the eruption (at the bottom of the magma reservoir, represented by the sample Cal-160) are consistent with the seismic signals detected just before this rapid-onset eruption (SERNAGEOMIN 2015c; Valderrama et al. 2015; Fig. 4). The absence of deformation until at most 1.5 days before the first eruptive pulse (Valderrama et al. 2015; Delgado et al. 2017) suggests that there were no major volumetric changes related to an ascent of volatiles or increased magma supply into the reservoir prior to the eruption. In addition, $67 \%$ of the calculated timescales lie within a 36 -h window prior to the eruption, suggesting that most of the heating of the sample Cal-160 is recorded during that period. Furthermore, the peak density of the modelled timescales representing the heating of the reservoir coincides with the occurrence of the seismic swarm, starting around $3 \mathrm{~h}$ before the first eruptive event (Fig. 4).

Neither tilt nor interferograms that span the $36 \mathrm{~h}$ prior to the eruption, nor the co-eruptive period, show any evidence of major volume increase during the heating event (Valderrama et al. 2015; Delgado et al. 2017). Our results are consistent with the triggering mechanism of a small mafic injection proposed by Castruccio et al. (2016), and similar to short-timescale processes suggested for large magmatic systems by Burgisser and Bergantz (2011), during which magma recharge adds heat and volatiles with the latter stalling below the mush reservoir causing crystal mush disaggregation, magma remobilisation (rheological unlock-up point of crystal
Table 2 Fe-Ti oxide rim intensive conditions (during heating) and associated timescales of ilmenitetitanomagnetite pairs from sample Cal-160

\begin{tabular}{lclllllllrr}
\hline Pair & $T\left({ }^{\circ} \mathrm{C}\right)$ & Error & $f \mathrm{O}_{2}(\Delta \mathrm{NNO})$ & Error & $X_{\text {usp }}$ & Error & $D_{\mathrm{Ti}}^{*}$ & Min $t(\mathrm{~h})$ & Time $(\mathrm{h})$ & $\operatorname{Max} t(\mathrm{~h})$ \\
\hline ff_p1 & 1073 & 23 & 0.21 & 0.09 & 0.55 & 0.011 & $2.29 \times 10^{-16}$ & 2 & 3.8 & 7 \\
f17_p1 & 1029 & 19 & 0.4 & 0.07 & 0.47 & 0.009 & $1.09 \times 10^{-16}$ & 6.9 & 12.2 & 21.7 \\
fe_p1 & 1015 & 18 & 0.43 & 0.06 & 0.46 & 0.009 & $8.51 \times 10^{-17}$ & 5.3 & 8.7 & 14.9 \\
f13_p1 & 1013 & 16 & 0.61 & 0.05 & 0.42 & 0.009 & $8.54 \times 10^{-17}$ & 6.5 & 10.9 & 18.4 \\
f17_p2 & 1048 & 14 & 0.75 & 0.03 & 0.42 & 0.009 & $1.66 \times 10^{-16}$ & 2.4 & 3.8 & 6.1 \\
fh_p1 & 1068 & 15 & 0.64 & 0.03 & 0.45 & 0.009 & $2.25 \times 10^{-16}$ & 10.1 & 16.2 & 26.2 \\
ff_p2 & 947 & 19 & 0.27 & 0.09 & 0.42 & 0.009 & $2.2 \times 10^{-17}$ & 10.5 & 19.7 & 36.2 \\
fb_p1 & 952 & 18 & 0.32 & 0.09 & 0.42 & 0.009 & $2.44 \times 10^{-17}$ & 14.8 & 26.7 & 45.8 \\
f1_p1 & 1067 & 17 & 0.5 & 0.05 & 0.47 & 0.009 & $2.12 \times 10^{-16}$ & 20.2 & 33.8 & 56.7 \\
f1_p3 & 1005 & 15 & 0.56 & 0.05 & 0.42 & 0.009 & $7.3 \times 10^{-17}$ & 45.6 & 75.8 & 126.2 \\
f1_p2 & 1041 & 14 & 0.55 & 0.04 & 0.45 & 0.008 & $1.4 \times 10^{-16}$ & 41.1 & 65.9 & 105.5 \\
f17_p4 & 963 & 17 & 0.47 & 0.08 & 0.40 & 0.008 & $3.17 \times 10^{-17}$ & 31.7 & 58.3 & 91.2 \\
\hline
\end{tabular}


Fig. 4 a Plots of modelled timescales from heating to eruption of 12 in-contact ilmenite-titanomagnetite pairs with associated errors based on temperature, oxygen fugacity and intrinsic diffusivity uncertainties; b kernel density estimation of probability distributions of all data, probabilities of several ranges of time are shown (details in Supplementary Material 5); c summary of geophysical signals at Calbuco in $140 \mathrm{~h}$ preceding the second phase of the eruption at 4:00 (UTC) on 23 April.

Sentinel-1a interferograms show no deformation in the months before and at least up until $36 \mathrm{~h}$ before eruption onset (descending, track 83, 21/04/2015, 09:57

UTC). VT swarms began $3 \mathrm{~h}$ before the first eruptive pulse (18:11 UTC; SERNAGEOMIN 2015c; Valderrama et al. 2015). A thermal anomaly was detected by NOAA's Geostationary Operational Environmental Satellite (GOES-13) $20 \mathrm{~min}$ prior to the first eruptive pulse (20:45 UTC; Global Volcanism Program 2015)

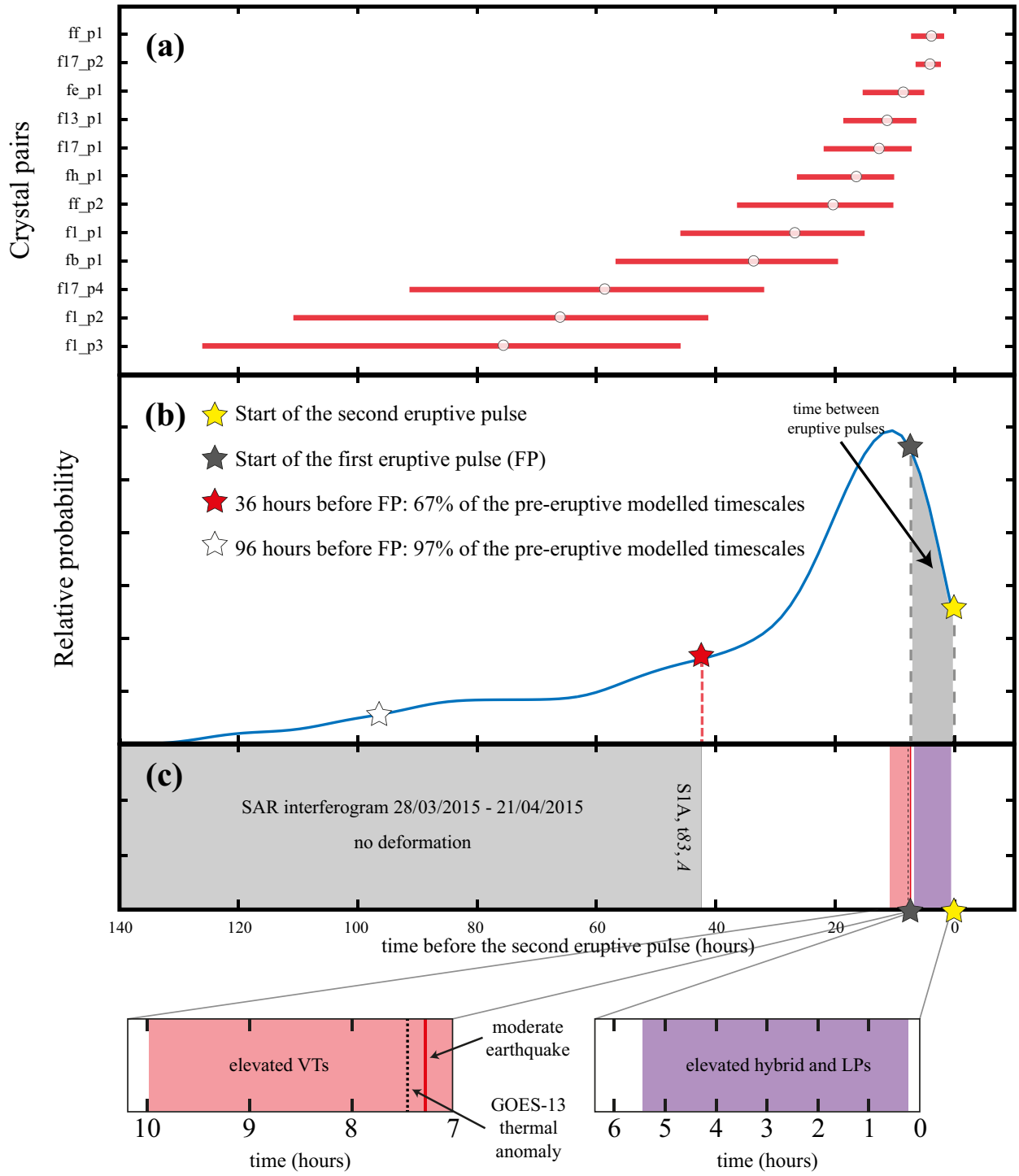

mushes, cf. Vigneresse et al. 1996; Petford 2003; Huber et al. 2011; Parmigiani et al. 2014) and eruption. Although bubbles can ascend via infiltration or volatile-rich plumes with minor (or null) contents of attached new (presumably mafic) underlying magma (Phillips and Woods 2002; Bachmann and Bergantz 2006), there is no direct evidence of syn-eruptive magma mixing, liquid mingling or resorption features from the new, hotter magma. This is consistent with the models that indicate crystal mush and volatile systems would act as a rheological barrier to the inputs of new, presumably more mafic magma (Girard and Stix 2009; Huber et al. 2009, 2010). In absolute terms, the rims of the Fe-Ti oxide pairs from Cal-160 are much more oxidised, two to three orders of magnitude in absolute $f \mathrm{O}_{2}$ values, than the cores of the same sample. The bulk of this change in $\mathrm{fO}_{2}$ is close to the NNO buffer trend and represents the effect of heating that the crystals record. These variations could be real, and could represent a degree of heterogeneity in the magma system, potentially related to volatile distributions, or could be an artefact of the difficulty of obtaining reliable measurements of $f \mathrm{O}_{2}$. The obtained values of $f \mathrm{O}_{2}$ buffer from the Cal-160 $\mathrm{Fe}-\mathrm{Ti}$ oxide pairs correspond to $+0.48 \Delta \mathrm{NNO}(\sigma=0.16$ $\Delta \mathrm{NNO}$ ) and are comparable to uncertainties published in other articles (e.g., Borisov and Shapkin 1990; Ghiorso and Evans 2008). Regarding volatile phases during the eruption, Pardini et al. (2018) proposed the existence of exsolved volatiles $\left(\mathrm{H}_{2} \mathrm{O}, \mathrm{CO}_{2}, \mathrm{Cl}\right.$, and $\left.\mathrm{SO}_{2}\right)$ before the onset of the first eruptive event, thus the recognised triggering heating event could be associated with a terminal input of volatiles. This could, in turn, be regarded as consistent with an increase in seismic activity (Linde et al. 1994).

\section{Cal-149Tb and Cal-155}

The absence of significant variations in both temperature and oxygen fugacity recorded in the ilmenite-titanomagnetite 
Table $3 \mathrm{Fe}-\mathrm{Ti}$ oxide rim intensive conditions and associated timescales of re-equilibration of ilmenite-titanomagnetite pairs from samples Cal$149 \mathrm{~Tb}$ and Cal-155

\begin{tabular}{lllllllllll}
\hline Pair & $T\left({ }^{\circ} \mathrm{C}\right)$ & Error & $f \mathrm{O}_{2}(\Delta \mathrm{NNO})$ & Error & $X_{\text {usp }}$ & Error & $D_{\mathrm{Ti}}^{*}$ & Time (years) & Min $t$ (years) & Max $t($ years $)$ \\
\hline Cal-149Tb_fig14b_p1 & 966 & 22 & 0.45 & 0.09 & 0.44 & 0.01 & $3.6 \times 10^{-17}$ & 8 & 5 & 13 \\
Cal-149Tb_fig14_p2 & 961 & 22 & 0.36 & 0.1 & 0.46 & 0.01 & $3.2 \times 10^{-17}$ & 1 & 0.5 & 1.5 \\
Cal-155_fig3_p1 & 903 & 20 & 0.21 & 0.11 & 0.40 & 0.01 & $8.6 \times 10^{-18}$ & 6 & 3.5 & 8.5 \\
Cal-155_fig24_p1 & 902 & 21 & 0.17 & 0.1 & 0.39 & 0.01 & $8.2 \times 10^{-18}$ & 4 & 2.5 & 7 \\
\hline
\end{tabular}

pairs of the lower crystallinity samples ( 40\% crystallinity, i.e., all except Cal-160) suggest that the heating effect was at a local scale, only occurring in a relatively small volume of the magma reservoir at the base of the reservoir and not thermally affecting the rest of the reservoir (Morgado et al. 2019). Our modelled re-equilibration timescales of $>1$ year (Table 3) represents the minimum duration over which temperature and $f \mathrm{O}_{2}$ conditions for the bulk of the erupted magma reservoir beneath Calbuco volcano were stable, prior to the 2015 eruption.

Our calculated timescales, considering all the samples, suggest that the heating event, which triggered the April 2015 Calbuco eruption only significantly affected the bottom of the system over a maximum period of 4 days, but did not affect the upper levels of the reservoir. The middle of the reservoir was not affected by that heating or by any other event, and had already been established for over a year prior to the eruption. All the compositional profiles and videos of examples of diffusion are available as Supplementary Materials 1 and 7 , respectively.

\section{Concluding remarks}

As a consequence of the rapid rate of $\mathrm{Fe}-\mathrm{Ti}$ interdiffusion in $\mathrm{Fe}-\mathrm{Ti}$ oxides, these minerals can be used for the determination of short-timescale magmatic processes. In this study, magmatic timescales ranging from $2 \mathrm{~h}$ up to 4 days

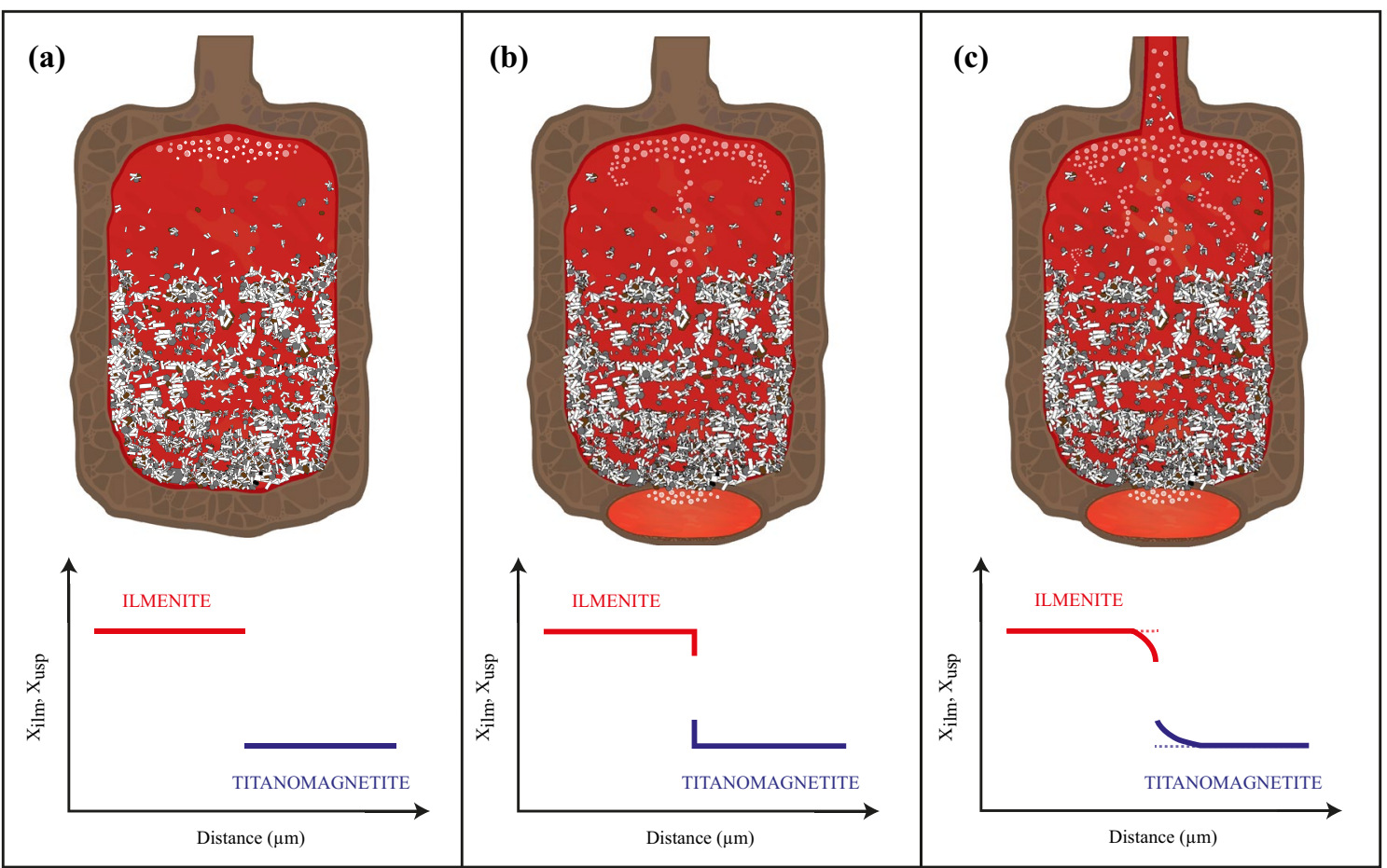

Fig. 5 a Before the hotter magma arrival (before the heating transfer event), the ilmenite-titanomagnetite profiles from the bottom of the crystal much are flat, they record temperature and oxygen fugacity; b at the moment of the heat transfer, $\mathrm{Fe}$ and $\mathrm{Ti}$ exchange between ilmenite and titanomagnetite instantaneously modifies compositions in the boundary between the two crystals from the base of the crystal mush. The internal diffusion within crystals starts at the same moment of the elemental exchange; $\mathbf{c}$ due to the heating, remobilisation and stirring of the system starts, overpressure increases and the eruption is triggered. At the moment of the eruption, temperature decreases and net diffusion ceases to be significant, so that the crystals from the bottom of the crystal mush recorded timescales from heating to eruption. Modified from Morgado et al. (2019) 
are calculated via $\mathrm{Fe}-\mathrm{Ti}$ interdiffusion profiles observed between ilmenite-titanomagnetite crystal pairs of the sample Cal-160 (the sample that represents the bottom of the reservoir), under known temperature and $f \mathrm{O}_{2}$ conditions. These timescales represent the time elapsed between local-scale heating at the base of the magma reservoir and the beginning of the rapid-onset 2015 Calbuco eruption (Fig. 5). We interpret these to represent the underplating of a high-temperature mafic melt, considerably hotter than the overlying magma body that would form the bulk of the erupted material during the eruption. There is seemingly no evidence for the mafic magma input to have directly erupted, and thus it would suggest that the eruption could have been triggered by a critical, physical failure related to overpressure following intrusion, rather than magma mixing or chemical interactions. Our results suggest that the peak of pre-eruptive activity occurred just $\sim 3 \mathrm{~h}$ prior to the eruption, coincident with the timing of a seismic swarm before the eruption onset.

By contrast, examination of $\mathrm{Fe}-\mathrm{Ti}$ interdiffusion in the $\mathrm{Fe}-\mathrm{Ti}$ oxides of the carrier magmas suggest minimum reequilibration timescales of $>1$ year in the samples Cal$149 \mathrm{~Tb}$ and Cal-155, interpreted to represent the middle of the reservoir (Morgado et al. 2019). This minimum timescale suggests that the bulk of the erupted magma has resided in a stable thermal and oxidation state for at least the year prior to the April 2015 Calbuco eruption and that the bulk of the magma residing into the reservoir was not thermally affected by the intrusion.

In summary, the 2015 Calbuco eruption involved an established magma body persisting under relatively stable conditions over the years-to-decades timescale, surrounded by a crystal mush envelope of similar origins. That system was disrupted and invaded by a pulse of mafic magma which did not produce any measurable surface deformation. This provided additional heat to the base of the magma system, disrupting a mush horizon, fragments of which would be incorporated into subsequent PDC deposits as materials like the sample Cal-160. Within hours to days of the intrusion event, VT earthquakes and subsequent LP seismicity were the heralds of the eruption commencing as the resident magmas ascended to the surface. The existence of a robust monitoring system at Calbuco strongly shows us that the run-up time to eruption at Calbuco was very short, giving us greater confidence in the relative lack of precursory activity compared to other, historical eruptions of the region. We hope that these results provide valuable insight into understanding the mechanism of rapid-onset explosive eruptions and potential methods by which to explore other, similar events for the purpose of eruption prediction and hazard mitigation.

Acknowledgements We acknowledge the help in the field of Marcela Vollmer. The financial support through FONDAP project 15090013 (Centro de Excelencia en Geotermia de los Andes, CEGA), CONICYT
Ph.D. fellowship (72160268, EM), hosted at Leeds by DJM, and Ph.D. fellowship Master Standard Grant to G. F. Zellmer (MAU1704, RB) are acknowledged. SKE is supported by a Leverhulme Early Career Fellowship and a Living Planet Fellowship from the European Space Agency. Fruitful discussions with the personnel from SERNAGEOMIN-OVDAS (Chile) are greatly appreciated. We would like especially thank Claire Harnett for comments and suggestions on reading an earlier version of this manuscript. We thank two anonymous reviewers for their detailed and constructive reviews. Editorial handling of $\mathrm{M}$. Ghiorso is greatly appreciated.

Open Access This article is distributed under the terms of the Creative Commons Attribution 4.0 International License (http://creativeco mmons.org/licenses/by/4.0/), which permits unrestricted use, distribution, and reproduction in any medium, provided you give appropriate credit to the original author(s) and the source, provide a link to the Creative Commons license, and indicate if changes were made.

\section{References}

Aggarwal S, Dieckmann R (2002a) Point defects and cation tracer diffusion in $\left(\mathrm{Ti}_{x} \mathrm{Fe}_{1-x}\right)_{3-\delta} \mathrm{O}_{4}$ 1. Non-stoichiometry and point defects. Phys Chem Miner 29(10):695-706. https://doi.org/10.1007/s0026 9-002-0282-2

Aggarwal S, Dieckmann R (2002b) Point defects and cation tracer diffusion in $\left(\mathrm{Ti}_{x} \mathrm{Fe}_{1-x}\right)_{3-\delta} \mathrm{O}_{4}$ II. Cation tracer diffusion. Phys Chem Miner 29(10):707-718. https://doi.org/10.1007/s0026 9-002-0284-0

Aragon R, McCallister RH, Harrison HR (1984) Cation diffusion in titanomagnetites. Contrib Mineral Petrol 85(2):174-185. https:// doi.org/10.1007/BF00371707

Bachmann O, Bergantz GW (2006) Gas percolation in upper-crustal silicic crystal mushes as a mechanism for upward heat advection and rejuvenation of near-solidus magma bodies. J Volcanol Geotherm Res 149(1-2):85-102. https://doi.org/10.1016/j.jvolg eores.2005.06.002

Bacon CR, Hirschmann MM (1988) Mg/Mn partitioning as a test for equilibrium between coexisting Fe-Ti oxides. Am Mineral 73(1-2):57-61

Borisov AA, Shapkin AI (1990) A new empirical equation rating $\mathrm{Fe}^{3+} /$ $\mathrm{Fe}^{2+}$ in magmas to their composition, oxygen fugacity, and temperature. Geochem Int 27(1):111-116

Brenguier F, Shapiro NM, Campillo M, Ferrazzini V, Duputel Z, Coutant O, Nercessian A (2008) Towards forecasting volcanic eruptions using seismic noise. Nat Geosci 1(2):126. https://doi. org/10.1038/ngeo104

Burgisser A, Bergantz GW (2011) A rapid mechanism to remobilize and homogenize highly crystalline magma bodies. Nature 471(7337):212-215. https://doi.org/10.1038/nature09799

Carapezza ML, Federico C (2000) The contribution of fluid geochemistry to the volcano monitoring of Stromboli. J Volcanol Geotherm Res 95(1-4):227-245. https://doi.org/10.1016/S0377 -0273(99)00128-6

Castro JM, Dingwell DB (2009) Rapid ascent of rhyolitic magma at Chaitén volcano, Chile. Nature 461(7265):780. https://doi. org/10.1038/nature08458

Castruccio A, Clavero J, Segura A, Samaniego P, Roche O, Le Pennec J, Droguett B (2016) Eruptive parameters and dynamics of the April 2015 sub-Plinian eruptions of Calbuco volcano (Southern Chile). Bull Volcanol 327:469-483. https://doi.org/10.1007/s0044 5-016-1058-8 
Chertkoff DG, Gardner JE (2004) Nature and timing of magma interactions before, during, and after the caldera-forming eruption of Volcán Ceboruco, Mexico. Contrib Mineral Petrol 146(6):715735. https://doi.org/10.1007/s00410-003-0530-6

Coombs ML, Eichelberger JC, Rutherford MJ (2000) Magma storage and mixing conditions for the 1953-1974 eruptions of Southwest Trident volcano, Katmai National Park, Alaska. Contrib Mineral Petrol 140(1):99-118. https://doi.org/10.1007/s0041 00000166

Delgado F, Pritchard M, Lohman R, Naranjo JA (2014) The 2011 Hudson volcano eruption (Southern Andes, Chile): pre-eruptive inflation and hotspots observed with InSAR and thermal imagery. Bull Volcanol 76(5):815. https://doi.org/10.1007/s00445-014-0815-9

Delgado F, Pritchard ME, Ebmeier S, González P, Lara L (2017) Recent unrest (2002-2015) imaged by space geodesy at the highest risk Chilean volcanoes: Villarrica, Llaima, and Calbuco (Southern Andes). J Volcanol Geotherm Res 344:270-288. https ://doi.org/10.1016/j.jvolgeores.2017.05.020

Devine JD, Rutherford MJ, Norton GE, Young SR (2003) Magma storage region processes inferred from geochemistry of $\mathrm{Fe}-\mathrm{Ti}$ oxides in andesitic magma, Soufriere Hills Volcano, Montserrat, WI. J Petrol 44(8):1375-1400. https://doi.org/10.1093/petro $\log / 44.8 .1375$

Drouin D, Couture AR, Joly D, Tastet X, Aimez V, Gauvin R (2007) CASINO V2. 42-a fast and easy-to-use modeling tool for scanning electron microscopy and microanalysis users. Scanning 29(3):92-101. https://doi.org/10.1002/sca.20000

Ebmeier SK, Andrews BJ, Araya MC, Arnold DWD, Biggs J, Cooper C, Cottrell E, Furtney M, Hickey J, Jay J, Lloyd R, Parker AL, Pritchard M, Robertson E, Venzke E, Williamson JL (2018) Synthesis of global satellite observations of magmatic and volcanic deformation: implications for volcano monitoring and the lateral extent of magmatic domains. J Appl Volcanol 7(1):2. https://doi. org/10.1186/s13617-018-0071-3

Einarsson P (2018) Short-term seismic precursors to Icelandic eruptions 1973-2014. Front Earth Sci 6:45. https://doi.org/10.3389/ feart.2018.00045

Freer R, Hauptman Z (1978) An experimental study of magnetitetitanomagnetite interdiffusion. Phys Earth Planet Inter 16(3):223231. https://doi.org/10.1016/0031-9201(78)90015-8

Ghiorso MS, Evans BW (2008) Thermodynamics of rhombohedral oxide solid solutions and a revision of the $\mathrm{Fe}-\mathrm{Ti}$ two-oxide geothermometer and oxygen-barometer. Am J Sci 308:957-1039. https://doi.org/10.2475/09.2008.01

Ghiorso MS, Sack O (1991) Fe-Ti oxide geothermometry: thermodynamic formulation and the estimation of intensive variables in silicic magmas. Contrib Mineral Petrol 108(4):485-510. https:// doi.org/10.1007/BF00303452

Girard G, Stix J (2009) Buoyant replenishment in silicic magma reservoirs: experimental approach and implications for magma dynamics, crystal mush remobilization, and eruption. J Geophys Res Solid Earth. https://doi.org/10.1029/2008JB005791

Global Volcanism Program (2015) Report on Calbuco (Chile). In: Venzke E (ed) Bulletin of the Global Volcanism Network, 40:6. Smithsonian Institution

Gualda GAR, Pamukcu AS, Ghiorso MS, Anderson AT Jr, Sutton SR, Rivers ML (2012) Timescales of quartz crystallization and the longevity of the Bishop giant magma body. PLoS One. https:// doi.org/10.1371/journal.pone.0037492

Hall M, Ramón P, Mothes P, LePennec JL, García A, Samaniego P, Yepes H (2004) Volcanic eruptions with little warning: the case of Volcán Reventador's Surprise November 3, 2002 Eruption, Ecuador. Rev Geol Chile 31(2):349-358. https://doi.org/10.1007/ BF00303452
Hammond PA, Taylor LA (1982) The ilmenite/titano-magnetite assemblage: kinetics of re-equilibration. Earth Planet Sci Lett 61(1): $143-150$

Hartley ME, Morgan DJ, Maclennan J, Edmonds M, Thordarson T (2016) Tracking timescales of short-term precursors to large basaltic fissure eruptions through $\mathrm{Fe}-\mathrm{Mg}$ diffusion in olivine. Earth Planet Sci Lett 439:58-70. https://doi.org/10.1016/j. eps1.2016.01.018

Hovington P, Drouin D, Gauvin R (1997) CASINO: a new Monte Carlo code in C language for electron beam interaction-part I: description of the program. Scanning 19(1):1-14. https://doi.org/10.1002/ sca.4950190101

Huber C, Bachmann O, Manga M (2009) Homogenization processes in silicic magma chambers by stirring and mushification (latent heat buffering). Earth Planet Sci Lett 283(1-4):38-47. https://doi. org/10.1016/j.epsl.2009.03.029

Huber C, Bachmann O, Manga M (2010) Two competing effects of volatiles on heat transfer in crystal-rich magmas: thermal insulation vs defrosting. J Petrol 51(4):847-867. https://doi.org/10.1093/ petrology/egq003

Huber C, Bachmann O, Dufek J (2011) Thermo-mechanical reactivation of locked crystal mushes: melting-induced internal fracturing and assimilation processes in magmas. Earth Planet Sci Lett 304(3-4):443-454. https://doi.org/10.1016/j.epsl.2011.02.022

Lasaga AC (1979) Multicomponent exchange and diffusion in silicates. Geochim Cosmochim Acta 43(4):455-469. https://doi. org/10.1016/0016-7037(79)90158-3

Lasaga AC (1983) Geospeedometry: an extension of geothermometry. In: Saxena SK (ed) Kinetics and equilibrium in mineral reactions. Advances in physical geochemistry, vol 3. Springer, New York, pp 81-114

Lasaga AC, Jiang J (1995) Thermal history of rocks; P-T-t paths for geospeedometry, petrologic data, and inverse theory techniques. Am J Sci 295(6):697-741. https://doi.org/10.2475/ajs.295.6.697

Linde AT, Sacks IS, Johnston MJS, Hill SP, Bilham RG (1994) Increased pressure from rising bubbles as a mechanism for remotely triggered seismicity. Nature 371:29. https://doi. org/10.1038/371408a0

Loomis TP (1983) Compositional zoning of crystals: a record of growth and reaction history. In: Saxena SK (ed) Kinetics and equilibrium in mineral reactions. Advances in physical geochemistry, vol 3. Springer, New York, pp 1-60

López-Escobar L, Parada MÁ, Moreno H, Frey FA, Hickey-Vargas RL (1992) A contribution to the petrogenesis of Osomo and Calbuco volcanoes, Southern Andes $\left(41^{\circ} 00^{\prime}-41^{\circ} 30^{\prime} \mathrm{S}\right)$ : comparative study. Andean Geol 19(2):211-226

Madonia P, Rizzo AL, Diliberto IS, Favara R (2013) Continuous monitoring of fumarole temperatures at Mount Etna (Italy). J Volcanol Geotherm Res 257:12-20. https://doi.org/10.1016/j.jvolgeores .2013.03.001

Martin VM, Morgan DJ, Jerram DA, Caddick MJ, Prior DJ, Davidson JP (2008) Bang! Month-scale eruption triggering at Santorini volcano. Science 321(5893):1178. https://doi.org/10.1126/scien ce. 1159584

Morgado E, Morgan DJ, Harvey J, Parada MÁ, Castruccio A, Brahm R, Gutiérrez F, Georgiev B, Hammond SJ (2019) Localised heating and intensive magmatic conditions prior the 22-23 April 2015 Calbuco volcano eruption (Southern Chile). Bull Volcanol 81:24. https://doi.org/10.1007/s00445-019-1280-2

Nakamura M (1995) Continuous mixing of crystal mush and replenished magma in the ongoing Unzen eruption. Geology 23(9):807810. https://doi.org/10.1130/0091-7613(1995)023\%3c080 7:CMOCMA\%3e2.3.CO;2

Nikkhoo M, Walter TR, Lundgren PR, Prats-Iraola P (2016) Compound dislocation models (CDMs) for volcano deformation analyses. Geophys J Int 208:877-894. https://doi.org/10.1093/gji/ggw427 
Pardini F, Burton M, Arzilli F, La Spina G, Polacci M (2018) $\mathrm{SO}_{2}$ emissions, plume heights and magmatic processes inferred from satellite data: the 2015 Calbuco eruptions. J Volcanol Geotherm Res 361:12-24. https://doi.org/10.1016/j.jvolgeores.2018.08.001

Parmigiani A, Huber C, Bachmann O (2014) Mush microphysics and the reactivation of crystal-rich magma reservoirs. J Geophys Res Solid Earth 119(8):6308-6322. https://doi.org/10.1002/2014J B011124

Petford N (2003) Rheology of granitic magmas during ascent and emplacement. Annu Rev Earth Planet Sc 31(1):399-427. https:// doi.org/10.1146/annurev.earth.31.100901.141352

Phillips JC, Woods AW (2002) Suppression of large-scale magma mixing by melt-volatile separation. Earth Planet Sc Lett 204(1-2):4760. https://doi.org/10.1016/S0012-821X(02)00978-0

Roggensack K, Williams SN, Schaefer SJ, Parnell RA (1996) Volatiles from the 1994 eruptions of Rabaul: understanding large caldera systems. Science 273(5274):490-493. https://doi.org/10.1126/ science. 273.5274 .490

Romero JE, Morgavi D, Arzilli F, Daga R, Caselli A, Reckziegel F, Viramonte J (2016) Eruption dynamics of the 22-23 April 2015 Calbuco Volcano (Southern Chile): analyses of tephra fall deposits. J Volcanol Geotherm Res 317:15-29. https://doi.org/10.1016/j. jvolgeores.2016.02.027

Rutherford MJ, Baker L, Pallister JS (1993) Petrologic constraints of timing of magmatic processes in the 1991 Pinatubo volcanic system. EOS Trans Am Geophys Union 74:671

Sauerzapf U, Lattard D, Burchard M, Engelmann R (2008) The titanomagnetite-ilmenite equilibrium: new experimental data and thermo-oxybarometric application to the crystallization of basic to intermediate rocks. J Petrol 49(6):1161-1185. https://doi. org/10.1093/petrology/egn021

Sellés D, Moreno H (2011) Geología del Volcán Calbuco, Región de Los Lagos. Carta Geológica de Chile. Serie Geológica Básica, No. 130. Escala 1:50.000

SERNAGEOMIN (2015a) Reporte especial de actividad volcánica (REAV). Región de los Lagos, 2015, abril 22, 15:00
SERNAGEOMIN (2015b) Reporte especial de actividad volcánica (REAV). Región de los Lagos, 2015, abril 22, 20:45

SERNAGEOMIN (2015c) Reporte especial de actividad volcánica (REAV). Región de los Lagos, 2015, abril 22, 17:30

SERNAGEOMIN (2016) Ranking de los 90 volcanes activos de Chile. http://sitiohistorico.sernageomin.cl/archivos/Ranking-de-Volca nes.pdf. Accessed Jan 2019

SERNAGEOMIN (2017) Volcán Calbuco. http://www.sernageomin.cl/ volcan-calbuco. Accessed Jan 2019

Tomiya A, Miyagi I, Saito G, Geshi N (2013) Short time scales of magma-mixing processes prior to the 2011 eruption of Shinmoedake volcano, Kirishima volcanic group, Japan. Bull Volcanol 75(10):750. https://doi.org/10.1007/s00445-013-0750-1

Valderrama Ó, Franco L, Gil-Cruz F (2015) Erupción intempestiva del volcán Calbuco, Abril 2015. XIV Congreso Geológico Chileno III:91-93

Van Eaton AR, Amigo Á, Bertin D, Mastin LG, Giacosa RE, González J, Valderrama Ó, Fontjin K, Behnke SA (2016) Volcanic lightning and plume behavior reveal evolving hazards during the April 2015 eruption of Calbuco volcano, Chile. Geophys Res Lett 43(7):3563-3571. https://doi.org/10.1002/2016GL068076

Van Orman JA, Crispin KL (2010) Diffusion in oxides. Rev Mineral Geochem 72(1):757-825. https://doi.org/10.2138/rmg.2010.72.17

Venezky DY, Rutherford MJ (1999) Petrology and Fe-Ti oxide reequilibration of the 1991 Mount Unzen mixed magma. J Volcanol Geotherm Res 89(1):213-230. https://doi.org/10.1016/ S0377-0273(98)00133-4

Vigneresse JL, Barbey P, Cuney M (1996) Rheological transitions during partial melting and crystallization with application to felsic magma segregation and transfer. J Petrol 37(6):1579-1600. https ://doi.org/10.1093/petrology/37.6.1579

Publisher's Note Springer Nature remains neutral with regard to jurisdictional claims in published maps and institutional affiliations. 